\title{
IMPLEMENTASI SISTEM INFORMASI DESA DAN KAWASAN (SIDeKa) DALAM PERCEPATAN KEMANDIRIAN DESA DI DESA PAMOLOKAN KABUPATEN SUMENEP
}

\author{
Oleh : \\ Laila Istiqhfarah $^{1)}$, Irma Irawati Puspaningrum ${ }^{2)}$, Ach. Andiriyanto ${ }^{3)}$ \\ Fakultas Ilmu Sosial dan Ilmu Politik Program Studi Administrasi Publik ${ }^{1)}$, Dosen \\ Fakultas Ilmu Sosial dan Ilmu Politik ${ }^{2)}$, Dosen Fakultas Ilmu Sosial dan Ilmu Politik ${ }^{3)}$ \\ Universitas Wiraraja Madura \\ Email : lailaistiqhfarah17@gmail.com ${ }^{1)}$,irma@wiraraja.ac.id ${ }^{2)}$, \\ aryauri@wiraraja.ac.id ${ }^{3)}$
}

\begin{abstract}
The birth of Village Law No. 6 of 2014 gives authority to the village to take care and manage the affairs of its own government. Villages are required to develop their territory in accordance with the conditions and keep up with the times, one of which is the development of information technology. To encourage the village government in utilizing technology to provide information to its citizens, a system developed by $B P 2 D K$ is needed. This program is in the form of a technology platform based on the internet called SIDeKa. One of the villages that participated in implementing SIDeKa in Sumenep Regency is Pamolokan village, where Pamolokan is a village that took the initiative to make the village an informative village. The regulations that overshadow SIDeKa in Pamolokan village are contained in Perdes No. 4 of 2017 concerning RPJMDes. This research aims to determine the implementation of Village and Regional Information System (SIDeKa) in accelerating village independence in Pamolokan village, Sumenep Regency. The method used in this study is descriptive qualitative. The focus of this research is communication, resources, disposition, bureaucratic structure. Data and research results are obtained from observations, interviews with several informants and documentation. Pamolokan village is a village that has implemented technology named SIDeKa in its implementation developed in the form of a village website. But most people do not understand because of the lack of deep socialization to the community about the benefits of village websites.
\end{abstract}

Keywords : Village, Information Technology, SIDeKa

\begin{abstract}
Abstrak
Lahirnya Undang-Undang Desa No. 6 Tahun 2014 memberikan kewenangan kepada desa untuk mengurus dan mengatur urusan pemerintahannya sendiri. Desa dituntut untuk mengembangkan wilayahnya sesuai dengan kondisi dan mengikuti perkembangan zaman, salah satunya seperti perkembangan teknologi informasi. Guna mendorong pemerintah desa dalam memanfaatkan teknologi untuk memberikan informasi kepada warganya maka diperlukan suatu sistem yang dikembangkan oleh BP2DK. Program ini berbentuk platform teknologi berdasar pada internet yang diberi nama SIDeKa. Salah satu desa yang ikut mengimplementasikan SIDeKa di Kabupaten Sumenep adalah desa Pamolokan, yang dimana Pamolokan adalah desa yang berinisiatif membuat desanya menjadi desa informatif. Peraturan yang menaungi SIDeKa di desa Pamolokan terdapat di dalam Perdes No. 4 Tahun 2017 tentang RPJMDes. Penelitian ini bertujuan untuk mengetahui implementasi Sistem Informasi Desa dan Kawasan dalam percepatan kemandirian desa di desa Pamolokan Kabupaten
\end{abstract}


Sumenep. Metode yang digunakan dalam penelitian ini adalah deskriptif kualitatif. Fokus penelitian ini adalah komunikasi, sumberdaya, disposisi, struktur birokrasi. Data dan hasil penelitian diperoleh dari hasil observasi, wawancara dengan beberapa informan dan dokumentasi. Desa Pamolokan adalah desa yang telah mengimplementasikan teknologi yang diberi nama SIDeKa dalam pelaksanaannya dikembangkan dalam bentuk website desa. Namun sebagian besar masyarakat tidak memahami karena kurangnya sosialisasi yang mendalam kepada lapisan masyarakat mengenai manfaat website desa.

Kata Kunci : Desa, Teknologi Informasi, SIDeKa

\section{PENDAHULUAN}

Lahirnya Undang-Undang Desa

No. 6 Tahun 2014 dapat dikatakan sebagai proses mengembalikan kepercayaan negara kepada desa yang selama ini menjadi objek pembangunan baik dari kabupaten maupun pusat. Dengan dibuktikannya penerapan asas rekognisi dan asas subsidiaritas yang merupakan upaya konkret dalam mewujudkan kemandirian desa. Oleh sebab itu, desa merupakan cikal bakal dari terbentuknya bangsa dan penyelenggaraan pemerintahan desa sebagai subsistem dari sistem penyelenggaraan pemerintahan, sehingga desa memiliki wewenang untuk mengurus dan mengatur urusan pemerintahannya sendiri.

Maka dari itu, desa dituntut untuk mengembangkan wilayahnya sesuai dengan kondisi dan mengikuti perkembangan zaman, salah satunya seperti perkembangan teknologi informasi. Teknologi informasi adalah suatu teknologi yang digunakan untuk mengolah data, termasuk memproses, mendapatkan, menyusun, menyimpan, memanipulasi data dalam berbagai cara untuk menghasilkan informasi yang berkualitas, yaitu informasi yang relevan, akurat dan tepat waktu, yang digunakan keperluan pribadi, bisnis, dan pemerintahan dan merupakan informasi yang strategis untuk pengambilan keputusan (Tata Sutabri,2014:3)

$$
\text { Pada saat sekarang ini }
$$
seharusnya hampir semua pengelolaan pemerintahan bisa menyesuaikan dengan kemajuan teknologi informasi termasuk pemerintahan terkecil yaitu desa, karena desa adalah sebuah pemerintahan yang seharusnya bisa membuat inovasi-inovasi baru dalam memberikan pelayanan yang mudah dan cepat kepada masyarakat. Apalagi pada era teknologi, semua masyarakat sudah mengenal handphone berarti masyarakat sudah bisa mengakses informasi, sehingga desa seharusnya dapat memberikan pelayanan yang optimal agar masyarakat paham tentang kondisi informasi yang terbaru.

$$
\text { Selain itu, teknologi }
$$

informasi penting untuk dimanfaatkan untuk mewujudkan transparansi 
informasi ke berbagai pihak. Dengan begitu, masyarakat dapat ikut serta untuk mengetahui serta mengawasi kebijakan desa. Melihat kondisi ini, desa membutuhkan sebuah sistem informasi untuk mengelola data dan informasi serta menampung segala informasi terkait potensi yang ada di desa, sehingga masyarakat diharapkan mampu membangun desa menjadi lebih baik melalui informasi-Informasi yang diperoleh. Salah satu bentuk komitmen pemerintah guna mendorong pemerintah desa dalam memanfaatkan teknologi untuk memberikan informasi dan pelayanan yang baik kepada warganya, maka pemerintah mengeluarkan Undang-Undang No. 6 Tahun 2014 tentang Desa pada pasal 86 (2) yang berbunyi “ Pemerintah dan Pemerintah Daerah wajib mengembangkan sistem informasi Desa dan pembangunan kawasan perdesaan" yang harus di implementasikan.

$$
\text { Pada saat ini untuk }
$$
mengimplementasikan peraturan tersebut pemerintah mengembangkan sebuah program yang dinamakan SIDeKa (Sistem Informasi Desa dan Kawasan) yang dikembangkan oleh Badan Prakarsa Pemberdayaan Desa dan Kawasan (BP2DK) sebagai solusi mendorong kemandirian desa dan kawasan di Indonesia pada Desember 2014. SIDeKa merupakan program dari pemerintah yang diluncurkan oleh Kementerian Komunikasi dan Informasi (Kominfo).

Selanjutmya karena tidak ada aturan teknis yang mengatur tentang SIDeKa dalam peraturan perundangundangan, maka peraturan yang menaungi SIDeKa merujuk pada ketentuan Pasal 86 Undang-Undang Desa, yang telah mengamanatkan dengan memberikan hak kepada Desa atas akses melalui sistem informasi desa yang dikembangkan oleh Pemerintah Daerah Kabupaten/Kota serta hak pengelolaan sistem informasi desa. SIDeKa dikembangkan untuk mewujudkan desa mandiri yang demokratis, transparan dan akuntabel.

SIDeKa sudah digunakan di 5.632 desa di 62 kabupaten di 26 provinsi di Indonesia. Capaian ini terwujud berkat kesadaran dan keinginan desa untuk meningkatkan pelayanan kepada masyarakat. Selain itu, sistem ini tidak hanya dirancang untuk menyediakan pelayanan pemerintah desa kepada masyarakatnya, akan tetapi sistem ini juga dapat dimanfaatkan oleh pemerintah daerah sebagai pedoman dalam menentukan kebijakan pembangunan. Dalam hal ini SIDeKa 
akan menjadi pusat informasi untuk memberikan akses kepada masyarakat desa dan pemerintah pusat guna mendorong percepatan desa yang mandiri.

$$
\text { Selanjutnya implementasi }
$$

SIDeKa sepenuhnya di manajemen oleh desa, sehingga akan menjadi masalah tersendiri, karena dalam implementasiannya tidak semua desa bisa menerapkan system informasi desa dan kawasan (SIDeKa) disebabkan beberapa kendala diantaranya keterbatasan sarana, infrastruktur teknologi informasi dan komunikasi yang tidak merata di seluruh wilayah serta implementasi yang tidak di dukung oleh masyarakat seperti masyarakat yang hanya terbiasa menggunakan teknologi handphone untuk berkomunikasi tetapi tidak terbiasa menggunakan secara teknologi, sehingga dalam proses implementasi SIDeKa dibutuhkan dukungan tenaga ahli teknik informatika (TI) terutama dari perguruan tinggi. Dukungan tenaga ahli ini berasal dari dosen yang mengabdi dimaksudkan untuk melakukan pendampingan pemerintah desa dalam proses instalasi SIDeKa yang berbentuk website dan memberikan penjelasan tentang implementasi SIDeKa. Saat ini desa yang telah mengimplementasikan SIDeKa dalam upaya memberikan akses pelayanan kepada masyarakat terkait data dan informasi desa adalah Desa Pamolokan.

Desa Pamolokan adalah desa yang mendapat penghargaan menjadi desa informatif pada tahun 2019 dan telah membawa nama harum Kabupaten Sumenep dikancah regional. Dimana desa Pamolokan meraih 10 besar nominator desa informatif terbaik se Jawa Timur (matamaduranews.com diakses pada tanggal 5 Desember 2020). Penghargaan yang diterima oleh Desa Pamolokan sebagai salah satu Desa terbaik dalam mengelola website desa paling informatif di Jawa Timur.

$$
\text { Desa Pamolokan menerapkan }
$$

Sistem Informasi Desa dan Kawasan (SIDeKa) dengan melihat perkembangan zaman yang mengharuskan membuat suatu perubahan salah satunya dengan memanfaatkan teknologi sebagai inovasi dan sebagai upaya pemberian layanan informasi kepada masyarakat. Peraturan yang menaungi SIDeKa di desa Pamolokan terdapat di dalam Perdes No. 4 Tahun 2017 tentang RPJMDes. Namun dalam implementasiannya belum berjalan maksimal karena masih terdapat permasalahan seperti kurangnya 
dukungan dari pihak Kabupaten sehingga menyebabkan operator desa tidak termotivasi untuk mengupdate informasi dan data. Selain itu, sosialisasi yang tidak menyeluruh dilakukan pemerintah desa terkait adanya SIDeKa kepada masyarakat sehingga masih banyak masyarakat yang tidak mengetahui dan tidak menggunakan sistem yang digunakan oleh desa untuk memberikan kemudahan kepada masyarakat dalam mengakses informasi secara cepat dan akurat yang sesuai dengan kebutuhan masyarakat.

Dengan demikian, tanpa adanya partisipasi masyarakat maka sistem informasi hanyalah menjadi perangkat aparat desa yang kurang bermakna karena masyarakat merasa tidak memiliki. Oleh sebab itu, penelitian ini penting untuk dilaksanakan untuk mengatasi berbagai permasalahan di desa Pamolokan dalam mengimplementasikan SIDeKa yang mana masyarakat desa diharapkan mampu menggunakan data-data yang ada di SIDeKa untuk memperkuat kemandirian desa. Berdasarkan permasalahan dan fakta yang telah diungkap, maka peneliti tertarik untuk melakukan penelitian dengan judul "Implementasi Sistem Informasi Desa dan Kawasan
(Sideka) Dalam Percepatan

Kemandirian Desa Di Desa

Pamolokan Kabupaten Sumenep”.

\section{TINJAUAN TEORITIS}

\section{Implementasi}

Implementasi merupakan kegiatan yang penting dari keseluruhan proses perencanaan peraturan atau kebijakan. Menurut Gordon implementasi berkenaan dengan berbagai kegiatan yang diarahkan pada realisasi program. Dalam hal ini administrator mengatur cara untuk mengorganisir, menginterpretasikan dan menetapkan kebijakan yang telah diseleksi (Deddy Mulyadi, 2018:24).

Menurut Van Meter dan Van Horn merumuskan mengenai proses implementasi sebagai "those actions by public or private individuals (or groups) that are directed at the achievement of objectives set forth in prior policy decisions". Artinya tindakan yang dilakukan individu atau pejabat maupun swasta yang mengarah pada tujuan yang ditetapkan (Muhammad Ridha Suaib, 2016:81).

Menurut Mazmanian dan Sabatier menyatakan, "implementasi artinya memahami yang senyatanya sesudah suatu program dinyatakan berlaku atau dirumuskan yang mencakup usaha-usaha untuk 
mengadministrasikan maupun untuk menimbulkan dampak nyata pada masyarakat atau kejadian-kejadian" (Sutojo, 2015:3).

Selanjutnya menurut Pressman dan Wildavsky mengemukakan bahwa: "Implementation as to carry out, acoumplish, fulfill, produce, complete", artinya membawa, menyelesaikan, mengisi, menghasilkan, melengkapi. Jadi secara etimologis implementasi itu dapat dimaksudkan sebagai suatu aktifitas yang bertalian dengan penyelesaian suatu pekerjaan dengan penggunaan sarana (alat) untuk memperoleh hasil" (Erwan dan Dyah, 2015:20).

Selanjutnya George C. Edward mengemukakan beberapa 4 (empat) variable yang mempengaruhi Implementasi kebijakan (Deddy Mulyadi, 2018:68) yaitu :

a. Komunikasi

\section{Keberhasilan}

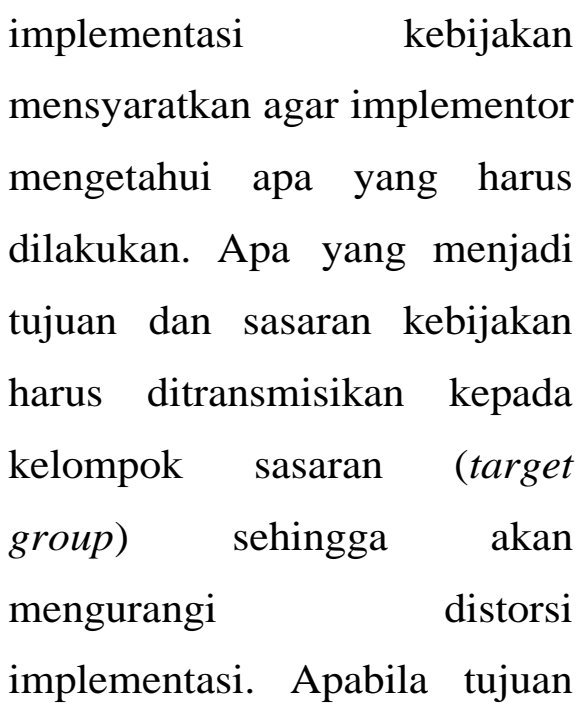

dan sasaran suatu kebijakan tidak jelas atau tidak diketahui sama sekali oleh kelompok sasaran, maka kemungkinan akan terjadi resistensi dari kelompok sasaran.

b. Sumberdaya

Walaupun isi kebijakan sudah dikomunikasikan secara jelas dan konsisten, tetapi apabila implementor kekurangan sumberdaya untuk melaksanakan, implementasi tidak akan berjalan efektif. Sumberdaya tersebut dapat berwujud sumberdaya manusia, yakni kompetensi implementor, dan sumberdaya finansial. Sumberdaya adalah faktor penting untuk implementasi kebijakan agar efektif. Tanpa sumber daya, kebijakan hanya tinggal di kertas menjadi dokumen saja.

c. Disposisi

Disposisi adalah watak dan karakteristik yang dimiliki oleh implementor, seperti komitmen, kejujuran, sifat demokratis. Apabila implementor memiliki disposisi yang baik, maka dia dapat menjalankan kebijakan dengan baik seperti apa yang diinginkan 
oleh pembuat kebijakan, maka proses implementasi kebijakan juga menjadi tidak efektif.

d. Struktur Birokrasi

Struktur organisasi yang bertugas mengimplementasikan kebijakan memiliki pengaruh yang signifikan terhadap implementasi kebijakan. Salah satu dari aspek struktur yang penting dari setiap organisasi adalah adanya prosedur operasi yang standar (standard operating procedure atau SOP). SOP menjadi baru bagi setiap implementor dalam bertindak. Struktur organisasi yang terlalu panjang akan cenderung mengawasi dan menimbulkan birokrasi, yakni prosedur birokrasi yang rumit dan kompleks. Ini pada organisasi yang menyebabkan organisasi tidak fleksibel.

\section{Sistem Informasi Manajemen}

Sistem informasi manajemen merupakan sekelompok atau sekumpulan proses dimana data dapat diolah, dianalisis, dan ditampilkan supaya data tersebut menjadi berguna untuk kebutuhan pengambilan suatu keputusan. Sistem informasi manajemen artinya data atau informasi yang dihasilkan dapat digunakan untuk pengambilan keputusan pada berbagai tingkat manajer yang meliputi 2 bidang (Suyadi Prawirosentono, 2011:121) yakni :

1. Meramalkan apa yang akan terjadi pada waktu yang akan datang dengan menganalisis data masa lalu sehingga dapat memberikan berbagai pilihan keputusan

2. Membuat perubahan atas keputusan atau prosedur saat ini sehingga diperoleh suatu keputusan yang lebih memadai untuk yang akan datang.

\section{Sistem}

informasi manajemen adalah sebuah sistem, yaitu rangkaian terorganisasi dari sejumlah

bagian/komponen yang secara bersamasama berfungsi atau bergerak

menghasilkan informasi untuk digunakan dalam manajemen perusahaan (Bambang Hartono, 2013:18).

Sistem informasi manajemen merupakan penerapan sistem informasi di dalam organisasi untuk mendukung informasi-informasi yang dibutuhkan oleh semua tingkatan manajemen (Lantip Diat Prasojo, 2013:9). 


\section{Desa Mandiri}

Menurut UU No.6 Tahun 2014 desa merupakan kesatuan masyarakat hukum yang memiliki batas wilayah yang berwenang untuk mengatur dan mengurus urusan pemerintahan, kepentingan masyarakat setempat berdasarkan prakarsa masyarakat, hak asal usul, dan/atau hak tradisional yang diakui dan dihormati dalam sistem pemerintahan Negara Kesatuan Republik Indonesia.

Desa adalah sebagai suatu gejala yang bersifat universal, yang terikat pada lokalitas tertentu baik sebagai tempat tinggal (secara menetap) maupun bagi pemenuhan kebutuhannya, dan terutama yang tergantung kepada pertanian, desadesa dimanapun cenderung memiliki karakteristik-karakteristik tertentu yang sama (Rahardjo, 2010:28).

Menurut Bertha desa atau dengan nama aslinya yang setingkat yang merupakan kesatuan masyarakat hukum masyarakat berdasarkan susunan asli adalah suatu "badan hukum" dan adalah pula "badan pemerintahan", yang merupakan bagian wilayah kecamatan atau wilayah yang melingkunginya (Nurcholis, 2011:4). Sedangkan Desa menurut Kartohadikoesoemo, desa ialah suatu kesatuan hukum, dimana bertempat tinggal suatu masyarakat yang berkuasa mengadakan pemerintahan sendiri (Didik G. Suharto, 2019:111).

\section{METODE PENELITIAN}

Metode yang digunakan dalam penelitian ini adalah kualitatif deskriptif. Penelitian ini menggunakan metode

penelitian kualitatif dengan jenis penelitian deskriptif, yakni prosedur penelitian yang menghasilkan data deskriptif berupa kata- kata atupun lisan dari orag-orang dan perilaku yang diamati (Moleong, 2014:4).

Fokus penelitian bertujuan untuk membatasi penelitian dalam satu atau lebih variable dan fokus penelitian sendiri menjadi hal yang sangat penting untuk melakukan sebuah observasi pengumpulan data akan lebih terarah. Fokus kajian dalam penelitian yang akan dilakukan mengacu pada model implementasi kebijakan publik yang dikemukan oleh George C. Edward III dalam Deddy Mulyadi (2018:68) menunjuk empat variable yang berperan penting dalam pencapaian keberhasilan implementasi dan variable ini peneliti tetapkan sebagai fokus penelitian dalam Implementasi Sistem Informasi Desa dan Kawasan dalam Percepatan Kemandirian Desa di Desa Pamolokan 
Kabupaten Sumenep sebagai berikut :

1. Komunikasi

2. Sumber Daya

3. Disposisi

\section{Struktur Birokrasi}

Subjek penelitian merupakan informan yang dapat membantu dalam proses penelitian dimana dimanfaatkan untuk memberikan informasi tentang hal yang akan di teliti. Disini subjek penelitian dapat di jadikan sumber data oleh peneliti untuk penelitian yang akan dilakukan. Subyek penelitan dalam penelitian ini meliputi :

1. Informan Kunci yaitu Kepala Desa dan Sekretaris Desa (Sekdes) Pamolokan Kabupaten Sumenep.

2. Informan Utama yaitu Operator desa Pamolokan.

3. Informan Pendukung yaitu terdiri dari 5 masyarakat desa Pamolokan.

Teknik pengumpulan data merupakan sesi dari serangkaian kegiatan penelitian yang mana pada sesi ini peneliti harus mengumpulkan data-data yang dibutuhkan oleh peneliti untuk menunjang terwujudnya penelitian yang akurat dan dapat terbukti kebenarannya. Adapun teknik pengumpulan data yang digunakan peneliti dalam penelitian ini melalui observasi (pengamatan), interview (wawancara) dan dokumentasi.

Analisis data dilakukan secara interaktif dan berlangsung secara tuntas, sehingga datanya sudah jenuh. Aktivitas dalam analisis data terdiri dari data reduction, data display, dan conclutions (Sugiyono, 2017:334).

\section{HASIL DAN PEMBAHASAN}

Implementasi SIDeKa di desa Pamolokan dalam pelaksanaannya masih belum optimal karena masih hanya sebagian masyarakat yang mengetahui dan masih ada juga yang belum mengetahui adanya penggunaan SIDeKa di Pamolokan. Berikut ini akan dipaparkan hasil penelitian terkait implementasi SIDeKa di desa Pamolokan yang dilakukan dengan beberapa informan.

\section{Komunikasi}

$\begin{array}{cclc} & \text { Komunikasi } & \text { merupakan salah } \\ \text { satu } & \text { variable } & \text { penting dalam }\end{array}$
mempengaruhi implementasi kebijakan. Komunikasi berkaitan dengan penyampaian informasi, ide, keterampilan, peraturan dan lain-lain dengan menggunakan sarana tertentu. Komunikasi sangat menentukan keberhasilan pencapaian tujuan dari implementasi kebijakan.

Dalam implementasi kebijakan hal yang perlu diperhatikan dalam komunikasi yaitu cara penyampaian 
pesan dan kejelasan pesan.

Komunikasi sesuai yang dikemukakan oleh George C. Edward dalam Deddy Mulyadi (2018:68) keberhasilan suatu implementasi kebijakan mensyaratkan agar pelaksana implementasi mengetahui apa yang harus dilakukan, dimana menjadi tujuan dan sasaran kebijakan harus ditransmisikan kepada kelompok sasaran (target group), sehingga meminimalisir distorsi implementasi. Dalam hal ini pesan yang disampaikan harus jelas, akurat dan konsisten sehingga pelaksana kebijakan tahu apa yang harus dilakukan.

Dalam implementasi SIDeKa di desa Pamolokan yang menjadi kelompok sasaran atau target group adalah masyarakat. Bentuk komunikasi yang dilakukan yaitu dengan cara sosialisasi. Sosialisasi yang dilakukan oleh pihak Kecamatan yang bertempat di Kecamatan Sumenep tersampaikan dengan jelas karena bahasa yang digunakan mudah dipahami oleh operator desa mengenai pelaksanaan program SIDeKa.

Selanjutnya, pelaksanaan sosialisasi yang dilakukan oleh pemerintah desa mengenai adanya website SIDeKa tidak tersampaikan kepada seluruh masyarakat, karena dalam hal ini sebagian masyarakat mengaku tidak mengetahui bahwa ada sosialisasi dari pihak desa maupun aparat desa mengenai adanya SIDeKa, sehingga menyebabkan sebagian masyarakat desa tidak mengetahui adanya penggunaan website desa yang bisa diakses oleh masyarakat. Selanjutnya website SIDeKa ini dapat melakukan komunikasi dua arah yang dimana menyediakan kolom komentar atau usulan elektronik namun kendala yang sering terjadi website sering tidak dapat diakses atau dibuka diakibatkan error system sehinggga hal ini dapat menghambat proses komunikasi.

\section{Sumber Daya}

Sumber daya menjadi syarat berjalannya suatu organisasi. Oleh sebab itu sumber daya merupakan faktor penting dalam pelaksanaan kebijakan. Menurut George C. Edward III dalam Deddy Mulyadi (2018:68), walaupun isi kebijakan sudah dikomunikasikan secara jelas dan konsisten, tetapi apabila implementor kekurangan sumber daya untuk melaksanakan, implementasi tidak akan berjalan efektif.

Sumber daya tersebut dapat berwujud sumber daya manusia yakni kompetensi implementor dan sumber daya finansial. Sumber daya adalah faktor penting untuk implementasi kebijakan agar efektif. Tanpa sumber 
daya kebijakan hanya tinggal di kertas menjadi dokumen saja. Sumber daya yang dapat mendukung pelaksanaan kebijakan dapat berwujud, seperti sumberdaya manusia, sumberdaya anggaran, sumberdaya fasilitas.

Dalam implementasi SIDeKa di desa Pamolokan, dibutuhkan beberapa sumber daya yang harus dipenuhi. Pertama adalah sumber daya manusia, untuk itu perlu adanya manajemen SDM yang baik agar dapat meningkatkan kinerja program. Pada pelaksanaan SIDeKa operator desa yang dipilih tidak berdasarkan kompetensi dibidang IT melainkan mendapatkan sumber daya manusia secara otodidak yang kemudian dikirim untuk diberikan pelatihan selama 3 bulan yang bertempat di Kecamatan Sumenep. Hal ini berpengaruh terhadap pelaksanaan website SIDeKa seperti masih banyak kolom menu dalam website desa yang belum terisi.

$\begin{array}{crr}\text { Selain } & \text { sumber } & \text { daya } \\ \text { manusia, fasilitas } & \text { atau } & \text { sarana }\end{array}$
penunjang juga dibutuhkan untuk mendukung pelaksanaan SIDeKa di desa Pamolokan yakni perangkat teknologi untuk mempermudah dan mempercepat penyelenggaraan pemerintahan desa, dalam hal ini fasilitas atau sarana penunjang seperti komputer dan wifi dengan kecepatan sebesar 2 Mbps sudah memadai. Sumber daya finansial (anggaran) juga merupakan sumber kekuatan dalam mendukung pelaksanaan website SIDeKa di desa Pamolokan. Dalam hal ini sumber anggaran didapatkan dari dana desa untuk setiap pembiayaan dan pengelolan terkait pelaksanaan website SIDeKa.

\section{Disposisi}

Salah satu faktor yang mempengaruhi efektifitas implementasi kebijakan adalah sikap implementor. Karakter penting yang harus dimiliki oleh pelaksana kebijakan misalnya kejujuran dan komitmen yang tinggi. Kejujuran mengarahkan implementor untuk tetap berada dalam asa program yang telah di gariskan. Pada pelaksanaan SIDeKa di desa Pamolokan operator desa sangat menjunjung tinggi kejujuran. Hal ini dapat dilihat operator desa yang sekaligus juga sebagai pembuat berita dalam memberikan informasi atau berita sesuai dengan fakta yang terjadi serta tidak memanipulasi data. Sedangkan komitmen yang tinggi dari pelaksana kebijakan akan membuat mereka selalu antusias dalam melaksanakan tugas, wewenang, fungsi, dan tanggung jawab sesuai dengan peraturan yang telah ditetapkan. Sikap dari pelaksana kebijakan 
akan sangat berpengaruh dalam implementasi kebijakan. Apabila implementor memiliki sikap yang baik maka mereka akan menjalankan dengan senang hati tetapi jika pandangan mereka berbeda dengan pembuat kebijakan maka proses implementasi akan mengalami banyak masalah dan tidak akan terlaksana dengan baik.

Hal tersebut selaras dengan pendapat menurut George C. Edward III dalam Deddy Mulyadi (2018:68), Disposisi adalah watak dan karakteristik yang dimiliki oleh implementor, seperti komitmen, kejujuran, sifat demokratis. Apabila implementor memiliki disposisi yang baik, maka dia dapat menjalankan kebijakan dengan baik seperti apa yang diinginkan oleh pembuat kebijakan, maka proses implementasi kebijakan juga menjadi tidak efektif.

Sikap dari pelaksana menunjukkan seberapa besar daya dukung struktur organisasi, nilai-nilai yang berkembang, hubungan dan komunikasi yang terjadi di internal organisasi dalam pelaksanaan kebijakan, dukungan dari luar maupun kelompok sasaran. Tanpa dukungan tersebut sulit untuk diharapkan dapat terlaksana dengan baik.

Dalam pelaksanaan SIDeKa komitmen dari kepala desa Pamolokan dalam mengimplementasikan SIDeKa diwujudkan dengan menyisihkan sebagian anggaran dana desa untuk pelaksanaan SIDeKa sebesar Rp 3.100.000 pada tahun 2020 kemarin. Pamolokan adalah desa yang berinisiatif membuat desanya menjadi desa informatif dengan segala penghargaan. Namun pada kenyataannya dalam implementasi SIDeKa di desa Pamolokan pemerintah Kabupaten tidak mensupport, padahal website SIDeKa ini mendukung $e$ goverment sebagai pemanfaatan teknologi untuk mendukung adanya transparansi dan akuntabilitas publik. Dalam hal ini dukungan atau support yang diinginkan desa Pamolokan berupa dukungan finansial dalam rangka menunjang pelaksanaan SIDeKa dan kesempatan untuk mengikuti kompetisi berikutnya.

Oleh sebab itu, karena tidak adanya support dari pemerintah Kabupaten baik dari segi finansial dan kesempatan dalam mengikuti kompetisi berikutnya mengakibatkan operator desa merasa tidak termotivasi untuk mengupdate informasi $\mathrm{di}$ website SIDeKa. Selain itu pelaksanaan SIDeKa juga membutuhkan kerjasama yang baik antara desa dan masyarakat. Peran serta aktif dari masyarakat sangat diperlukan, masyarakat dituntut untuk 
melek terhadap perkembangaan zaman yang serba teknologi sehingga diharapkan ikut aktif dalam membangun website untuk kemajuan desa Pamolokan.

\section{Struktur Birokrasi}

Dalam implementasi kebijakan harus memiliki struktur yang jelas karena struktur juga memiliki pengaruh yang penting dalam proses implementasi kebijakan. Kejelasan prosedur operasional standar akan memudahkan bagi aparat untuk melaksanakan kebijakan. Dikatakan struktur yang baik dan jelas yaitu struktur yang mempunyai SOP (Standard Operating Procedurs). Struktur birokrasi dari suatu organisasi yang ideal ditandai dengan adanya prosedur standar organisasi dengan ukuran standarnya (SOP) untuk menenggulangi kondisi yang akan dihadapi dalam implementasi kebijakan.

Menurut George C Edward II dalam Mulyadi (2018:68), bahwa Struktur organisasi yang bertugas mengimplementasikan kebijakan memiliki pengaruh yang signifikan terhadap implementasi kebijakan. Salah satu dari aspek penting dalam setiap organisasi adalah adanya prosedur operasional yang standar. SOP menjadi pedoman bagi setiap Implementor dalam bertindak.
Desa Pamolokan melaksanakan website SIDeKa karena inisiatif sendiri sehingga tidak memiliki struktur organisasi maupun SOP (Standard Operating Procedurs) yang secara khusus dibuat karena dalam pelaksanaannya tidak melibatkan pihak lain atau instansi terkait, sehingga pembagian tugas dalam implementasi SIDeKa hanya dilakukan oleh pihak operator desa Pamolokan itu sendiri.

\section{PENUTUP}

Sebagaimana yang telah dibahas dalam penelitian ini mengenai implementasi sistem informasi desa dan kawasan (SIDeKa) dalam percepatan kemandirian desa di desa Pamolokan Kabupaten Sumenep dengan menganalisis melalui empat model implementasi kebijakan maka dapat diambil kesimpulan yakni desa Pamolokan adalah desa yang telah mengimplementasikan teknologi yang diberi nama SIDeKa dalam pelaksanaannya dikembangkan dalam bentuk website desa. Namun sebagian besar masyarakat tidak memahami karena kurangnya sosialisasi yang mendalam kepada lapisan masyarakat mengenai manfaat website desa. Sumber daya dalam pelaksanaan SIDeKa di desa pamolokan sudah mendukung dimana kepala desa sudah 
menyediakan sarana dan prasana penunjang seperti komputer dan kecepatan wifi sebesar 2 Mbps. Selain itu, dukungan dan komitmen dari kepala desa juga diwujudkan dengan menyisihkan sebagian anggaran dana desa untuk pelaksanaan SIDeKa sebesar Rp 3.100.000 pada tahun 2020. Namun dilihat dari struktur birokrasinya, desa Pamolokan dalam melaksanakan SIDeKa tidak memiliki SOP dan tidak melibatkan pihak lain dari kepanitiaan birokrasi dari instansi terkait, ini merupakan inisiatif dari desa Pamolokan yang dilakukan kepala desa dan aparatur desa itu sendiri. Oleh sebab itu dalam pelaksanaannya dikelola oleh operator desa sendiri.

Berharap kepala desa mewajibkan semua urusan harus melalui SIDeKa dan itu perlu disampaikan dengan cara sosialisasi dengan mengadakan pertemuan meminta warga menggunakan SIDeKa juga berharap kepala desa dan operator desa tetap memiliki komitmen untuk mengembangkan SIDeKa lebih baik lagi dalam rangka mendukung $e$ government serta hendaknya juga menerbitkan SOP walaupun hanya satu orang yang menjalankan sehingga pengelolaannya jelas dan terarah.

\section{DAFTAR PUSTAKA}

\section{Sumber Buku}

Agus Purwanto, Erwan dan Dyah Ratih Sulistyastuti. 2015. Implementasi Kebijakan Publik : Konsep dan Aplikasinya di Indonesia. Yogyakarta: Gava Media

Hartono, Bambang. 2013. Sistem Informasi Manajemen berbasis computer. Jakarta: Rineke Cipta

Mulyadi, Deddy. 2018. Studi Kebijakan Publik dan Pelayanan Publik : Konsep dan Aplikasi Proses Kebijakan Publik Berbasis Analisis Bukti untuk Pelayanan Publik. Bandung: Alfabeta

Nurcholis, Hanif. 2011. Pertumbuhan \& Penyelenggaraan Pemerintahan Desa. Jakarta: Erlangga

Prasojo, Lantip Diat. 2013. Sistem Informasi Manajemen Pendidikan. Yogyakarta: UNY Press

Prawirosentono, Suyadi. 2011. Manajemen Operasi. Jakarta: PT Bumi Aksara

Suaib, Muhammad Ridha. 2016. Pengantar Kebijakan Publik : Dari Administrasi Negara, Kebijakan Publik, Administrasi Publik, Pelayanan Publik, Good Governance, Hingga Implementasi Kebijakan. 
Yogyakarta: Calpulis

Rahardjo.2010. Sosiologi Pedesaan

dan Pertanian. Yogyakarta:

Gadjah Mada University Press

Sutabri, Tata. 2014. Pengantar

Teknologi Informasi.

Yogyakarta: Andi

Sutojo. 2015. Good Corporate

Governance. Jakarta: PT Damar

Mulia Pustaka.

\section{Sumber Undang-Undang}

Undang-Undang Republik Indonesia

Nomor 6 Tahun 2014 Tentang Desa.

\section{Sumber Internet}

Mata MaduraNews.(2018, Januari

12).Desa Pamolokan

Sabet Penghargaan

Desa Informatif se Jatim.

Diakses dari

https://matamaduranews.com/des

a- pamolokan-sabet-

penghargaan-desa- informatif-se-

jatim/ 